\title{
A Small-Scale Event and a Big Impact-Is This Relationship Possible in the World of Sport? The Meaning of Heritage Sporting Events for Sustainable Development of Tourism-Experiences from Poland
}

\author{
Ewa Malchrowicz-Mośko and Joanna Poczta * \\ Department of Humanistic Foundations of Tourism and Recreation, Faculty of Tourism and Recreation, \\ E. Piasecki University School of Physical Education, 61-871 Poznan, Poland; malchrowicz@awf.poznan.pl \\ * Correspondence: jpoczta@awf.poznan.pl; Tel.: +48-609-185-090
}

Received: 20 October 2018; Accepted: 14 November 2018; Published: 19 November 2018

\begin{abstract}
The theoretical part of this article presents the meaning of sporting events for the tourism industry and the importance of sporting events at a small scale, as well as heritage sporting events for sustainable development of tourist destinations. The literature review shows that there is a clear research gap with respect to the analysis of economic and social impacts of small-scale events. The empirical research was conducted by the method of a diagnostic survey during three sporting events of different rank, which took place in Poland and represented various sports disciplines-running, horse riding, and swimming. A total of 2098 respondents took part in the study, including sports tourists and resident-hosts who took part in the studied events. The aim of the study was to examine whether there is a link between the rank of a sporting event, the development of tourism, and the impact on the host city's image. The results of the study showed that the highest additional tourism activity in the city on the occasion of participation in an event as an athlete or supporter was undertaken by the participants of the lowest ranked sporting event (Half-Marathon). They also gave the highest rating of the positive impact of a sporting event on the host city's image. The hosts also rated the highest social impact from the Half-Marathon (i.e., increased sense of pride, social integration, and local identity). Events related to the heritage of the sport of a given region and other smaller-scale sporting events, including mass sports and recreation events (e.g., marathons and other running events), provide an alternative to homogenized, commercial, and very expensive sporting events in the world and may contribute to the sustainable development of tourist regions. The research results show that big social potential lies in the organization of small-scale sports events. The reflections contained in this article may inspire the organization of small-scale sporting events and the continued care for sporting events related to the cultural heritage of a given region. Events of this kind successfully impact tourist revival and improvement of the regions' image.
\end{abstract}

Keywords: small-scale event; sporting event; heritage sporting event; sustainable development of tourism; heritage management; heritage and sustainability; sport tourism; sport management, non-hallmark events

\section{Introduction}

Post-modern sporting activity has increased tourist mobility among the societies of almost all continents on an unprecedented scale, and sport tourism - especially in the form of participation of tourists in sporting events-has gained in popularity. In today's world, sport plays an increasingly 
important social and cultural role and sport tourism should be seen as an autonomous phenomenon of our times, reflecting current trends, needs, and lifestyles. Never before has sport tourism enjoyed such popularity and the sporting and tourist activities of society have become a mega-trend in the post-modern world. It is estimated that $25-30 \%$ of the world's tourism economy is currently sport-related travel, and forecasts of tourism development for the coming years also indicate a further increase in travel motivated by sports [1]. The constantly growing number of sporting events of various rank (for professional and amateur athletes) and different scales of difficulty, constantly appearing new sports disciplines-which can already be practiced in almost every corner of the globe-are causing sport tourism to be developing as dynamically as never before and is slowly becoming a phenomenon of our times. Moreover, the twenty-first century began with the third generation of city marketing - cities become responsible for their economic development by marketing sporting events [2,3]. The popularity of sporting events among fans and athletes has led them to play a leading role in place marketing - promotion of cities, countries, and tourist regions.

Sport and tourism became major components of the globally developing entertainment industry, leaving their mark on both the material and media aspect of mass culture. As multidimensional social and cultural systems creating a network of interconnections on a local, regional, and national plane maintain multilateral relations with almost every aspect of social, cultural, and economic life, and appear to be a driving dynamic for their growth. They appear in almost every cultural circle in the world, building bridges and barriers between cultures, influencing national and international political decisions. Spectacular examples of the above are World Championship events and Olympic Games, which become events of cultural, media, economic, ecological, image, and political importance, especially when contests between athletes translate into contests between nations. Unfortunately, in many cases, it seems, the long-term consequences for the host cities of sporting events are negative. It appears that with increasing scale, the potential for sporting events to create negative impacts also increases. Despite this, little academic attention has been paid to the tourism potential of regular season domestic sport competitions, national championships, and local/regional sport. At these levels of sport, the potential for negative impact is minimal, while the tourism development potential that they offer remains largely unresearched [4]. Still much of the economic impact research to date has focused on mega-event impact, such as the Olympic Games or the FIFA World Cup, e.g., References [5,6]. There is still a clear research gap with respect to the analysis of economic impacts of small-scale events from a local perspective [7]. The same situation is evident with the tourist behaviors of sport tourists and intangible impacts of small-scale events on hosts.

This article in its theoretical part presents the meaning of sporting events for the tourism industry and the importance of sporting events at a small scale and heritage sporting events for sustainable development of tourist destinations. The authors indicate positive and negative impacts of sporting events as well. The second part of the article presents the results of empirical research. The empirical research was conducted by the method of a diagnostic survey during three sporting events of different sporting rank, which took place in Poland and represented various sports disciplines-running, horse riding, and swimming. A total of 2098 respondents took part in the study: sports tourists and resident-hosts who took part in the studied events. The aim of the study was to examine whether there is a link between the rank of a sporting event and the development of tourism and the impact on the host city's image. The results of the study showed that the highest additional tourism activity in the city on the occasion of participation in an event as an athlete or supporter was undertaken by the participants of the lowest ranked sporting event (Half-Marathon). They also gave the highest rating of the positive impact of a sporting event on the host city's image. The hosts also rated the highest social impact from the Half-Marathon (i.e., increased sense of pride, social integration, and local identity). Events related to the heritage of the sport of a given region and other smaller-scale sporting events, including mass sports and recreation events (e.g., marathons and other running events), provide an alternative to homogenized, commercial, and very expensive sporting events in the world and may contribute to the sustainable development of tourist regions. The research results show how big social 
potential lies in the organization of small-scale sports events. The reflections contained in this article may inspire the organization of small-scale sporting events and the care for sporting events related to the cultural heritage of a given region. Events of this kind successfully impact tourist revival and improvement of the regions' image.

\section{The Phenomenon of Sport Tourism in Post-Modern Times}

The tourism industry has started to recognize sport tourism, i.e., the experience of travel to engage in or view sport-related activities, as an important market. It is generally recognized that there are three types of sport tourism: active sport tourism, sporting event tourism, and heritage/nostalgia sport tourism. Sport tourism stands for travelling away from one's place of residence in order to engage in sports-related activities for recreation or competition, travelling to spectate at popular and elite sporting events, as well as travelling to visit famous sport attractions (i.e., halls of fame, sport museums, etc.) [8-11]. Since the mid-1990s, sport-related travel has received more attention as a topic for study both from academics and the sport and tourism industries. Two of the world's most influential agencies for sport and tourism, the International Olympic Committee (IOC) and the United Nations World Tourism Organization (UN WTO), reaffirmed their commitment to sport tourism on World Tourism Day, 27 September 2004. The cooperation between the IOC and the UN WTO began in 1999. They recognized the mutually beneficial relationship that sport and tourism can have as a tool for sustainable economic growth. Sustainability is one of the three pillars of Olympic Agenda 2020-the International Olympic Committee's strategic roadmap. Sport is an important enabler of sustainable development. IOC recognizes the growing contribution of sport to the realization of goals of the sustainable development idea [12].

Sport event tourism includes participation in mega-events, such as the Olympic Games or World Football Championships. An example of this form of sport tourism is also participation in amateur sporting events. This type of sport tourism pertains to sporting events such as tourist attractions and the sport tourists who travel to watch them. To combat seasonality and create or enhance their destination image, countries and cities around the world are increasingly hosting sporting events, from hallmark events, or mega-events, such as the Olympic Games, to regional events. A hallmark event is a large-scale event which occurs infrequently (i.e., annually) that is associated with a specific location. A mega-event is a one-time international level event of a large scale, such as the Olympic Games or FIFA World Cup. A small-scale event is a regular season or a smaller one-off sporting event, such as amateur and youth tournaments. Small-scale sports events require little in the way of public funding, usually operate within existing infrastructures, and are more manageable in terms of crowding and congestion than mega sporting events $[4,13,14]$. The competition among communities to host major events is intense because community leaders focus on the economic impact from event patrons, sponsorship deals, and television rights. In recent years, as community leaders have recognized the synergy between sport and tourism, they are increasingly looking to generate tourism by developing a destination image through hosting sporting events.

\subsection{Positive and Negative Effects of Sport Tourism in the Light of Sustainable Development}

Effects caused by a given sporting event can be called its legacy-something that will stay for the local community after the event is over (for the residents of the city and region in which the event takes place). The social legacy of a sporting event is a change in value systems of individuals and societies caused by sporting journeys, changes in behavior of tourists and local residents, their social structures, lifestyles, and quality of life [15]. The sporting event legacy constitutes all permanent and long-term changes for the local and international environment, which occur due to hosting the events. Whether sport tourism development takes the form of sporting events, active participation in sport, or sports heritage, it draws on local resources and forms part of the complex dynamic of daily life. Sports tourism has implications for residents, with destination communities in a position to benefit from, or absorb the costs of, the extent to which development is sustainable [16,17]. 
Modern sporting events' ability to attract tourists is a multifunctional social phenomenon; a driving force for action and emotion passed on to millions of people. These may have a lot in common, for instance, with reinforcing national pride as a result of victory of our own team or athlete, reinforcing the spirit of community or local identity. Organizing an important sporting event forces collaboration within the region as well between regions. Becoming known with the spectators serves as a positive stimulus for local pride, raising morale, which at the same time stimulates new ideas for making use of the potential of the city/region. Physical education is an excellent integrating factor for local communities. For example, in Germany in 2006, supporting their own football team was an opportunity to rebuild national pride among Germans. The Lillehammer Olympics (1994) facilitated the integration of the Norwegian nation, at the same time maintaining the opinion about the country as a place with rich tradition for winter sports. Sports events may increase the sense of happiness among the host community as well [18-20].

The experience of host cities and countries shows these changes may be not only positive but also negative. Especially major sporting events, which may cause a series of major negative side effects in regard to the local ecology, i.e., increased emissions of toxic substances. They also generate additional noise and waste. Environmental effects of sports tourism are unfortunately sometimes much more negative than positive [21]. Although analyses in the field of sustainable tourism and sustainable sport appear in the scientific literature, the question of the sustainable development of both spheres meeting in the form of sport tourism, especially in areas with special natural qualities, is much less discussed [16-18]. To fight the negative effects of sport tourism, the Green Games held in 1994 were organized for the first time in Lillehammer [9]. IOC believes the Olympic Movement has both an opportunity and a duty to contribute actively to global sustainability in line with the vision of building a better world through sport.

Major sporting events (especially the modern Olympic Games) are a highly interdisciplinary phenomenon. The current literature abounds with many examples of effects of these events: long-term, short-term, direct, indirect, expected, unexpected, desirable, and undesirable. Contemporary sporting events are an important part of the tourist product of cities. For many tourists, participation is the main motive for visiting a particular place. Others treat them as additional attractions, enriching the tourism offer of the agglomeration. Thanks to them, the cities stand out from the competition by developing their competitive advantage, and their authorities create an image of an interesting place to visit. Generally, two types of tourism should be distinguished: flow-on (i.e., at the time of the events; tourism activities beyond the event but around the time of the event) and future tourism [22,23]. The claim that sporting events bring financial benefits is almost a truism today [24]. Sporting events have a direct and indirect impact on the development of tourism [25-28]. Sporting events develop tourism, tourists spend large sums of money during their stay, indirectly also inhibiting the development of unemployment, and through numerous advertisements, they can improve the image of the tourist destination [29-31].

Cities and regions all over the world today have to cope with the effects of developing globalization trends. The contemporary world confronts cities with the challenges of economic, cultural, and social change. One such challenge is the competition between places that appear on different levels and fields of activity. This rivalry refers to resources, investment, the number of tourists, new residents, or the right to organize important cultural and sporting events [32]. Contemporary cities and regions compete for the desired opinions and social feelings, for example, the right image. A recognizable positive image is increasingly the main value of a place, which determines its competitive advantage in the territory market. Promoting cities is about creating a positive image-showing the location, economic, sporting, and cultural values of a place [33]. Positive reception of the city in the inner and outer environment determines the popularity of a place as a destination for travel, residence, education, or investment. International events taking place in a particular place help to promote it, discover it first for the spectator of the event, and further for potential tourists and investors-those who during the stay or through the broadcasts can get to know them better. Events can contribute to the creation or total change of the image of a place; a country or an entire nation. Improving the image 
with the participation of events takes place through: promoting the city in the media with emphasis on good organization and friendly atmosphere; friendly hospitality for the participants in the form of prepared hotel, catering, transport, security; providing various additional attractions to participants, such as cultural events; and guaranteed high level of the event. Sporting events, potentially providing economic, political, tourist, social, and cultural benefits, have a special place in the marketing of cities. For this reason, cities and regions strongly compete for the organization of important sporting events. Cities then gain media publicity and promote the place. In addition, attractive events and positive experiences are building destination loyalty. Some of them become excellent ambassadors of the host city. Experience has shown that increasing the recognition and prestige of the host country in the world is the greatest added value to the organization of a big sporting event [34,35].

In recent decades (since the great success of the Los Angeles and Barcelona Olympic Games), many cities, regions, and countries have introduced strategies for the systematic organization of sporting events and have allocated human and financial resources to attract prestigious sporting competitions [36]. Barcelona used the 1992 Olympic Games to promote the Catalonia region. Due to the organization of the Olympic Games in Barcelona, the positive impact of this event on the development of tourism in the city and its image has been noted. Thanks to good organization and great promotion, the capital of Catalonia has become recognizable all over the world. In addition, although the Spaniards ended with a deficit, in the long term the city gained. This phenomenon was so expressive that it was called the "Barcelona effect" [37]. The United Kingdom, the organizer of the London 2012 Summer Olympics and, in subsequent years, many other elite sports competitions of the highest rank, may serve as an example as well. Also, Turin was promoted through the Games as a tourist destination. The event enabled the presentation of the rich history and culture of the region. One year after the Games ended, the number of tourists increased by 150,000. Turin was then in fourth place among the most visited Italian cities, just behind Rome, Florence, and Venice. As a result of the London 2012 Games, the United Kingdom sought to improve its image as a creative, good place to live, visit, and engage in business. To this end, once the Games were over, a hundred more sporting events were organized there to sustain the media's interest in this region [27]. Recently, Russia and Qatar have successfully fought for the rights to host the world's largest sporting events. Russia has already hosted the extremely expensive winter Olympic Games (Sochi 2014) and the FIFA World Cup (2018). The current reality of Qatar, in turn, is the construction of breathtaking sports complexes, gigantic investments, and huge amounts of money spent on infrastructure. All that with a view to the 2022 World Cup, and then perhaps also the Olympic Games. Founded in 2006, the city of Lusail is being built especially for the football feast. Presently, many countries in the world compete to organize mega-events, such as the Olympic Games or football championships, because it is widely believed that such enterprises result in an economic gain for tourist destinations and improve the attractiveness of regions as potential tourist destinations. Towns and countries more often choose sports events as a means of advertisement, to make an impression in the global media and to improve their global image. Organizing mega-events brings about many economic, social, and cultural benefits. However, it needs to be pointed out that impacts of sporting events are not solely positive. Presently, a number of negative effects of organizing major sporting events can be observed; this includes the economy, social, and cultural influences as well as ecology.

The discussion over the mega sporting events legacy started as a result of an attempt to address the question of positive and negative effects of hosting them, not only in terms of economics, but also in terms of culture, society, and ecology. The notion of the Olympic legacy has been part of strategic documents of the International Olympic Committee since the 1990s as an important socio-political issue and research material for academics of different disciplines. The Olympic legacy can be defined as planned and unplanned, positive and negative, tangible and intangible aspects, produced by and for a sporting event, which last longer than the event itself [38]. However, the issue has become interesting not only for Olympic hosts, but also for researchers and sustainable development specialists 
who distinguish legacies such as tangible, intangible, social, cultural, ecological, economical, urban, and sporting (new sporting infrastructure or encouraging people to do sports) [39].

The organization of sporting events brings many economic and socio-cultural benefits. There is a chance that afterwards museums of sports or Olympics will be established in the city. In addition, cultural tourism is still developing during the course of the event-fans and athletes visit the city, museums, restaurants, etc. For this reason, territorial units are in strong competition for the organization of important sporting events. Previous experience shows that the increase in recognition and prestige of the host city in the world is one of the greatest added values of organizing a sporting event. The "Barcelona effect" is definitely worth mentioning as an example of a positive legacy. Now, Barcelona is a highly popular tourist destination, and it enjoys a very positive image among visitors, whether they come for business or leisure. Unfortunately, hosting the Olympic Games or UEFA Championships may cause a lot of financial problems. That was the case with the 1976 Summer Olympics in Montreal: Canadians were paying off their debts for thirty years. The losses could not be compensated by the income from tourism, which did not fully develop, as had been expected. The "Montreal effect" is, hence, the opposite of the "Barcelona effect". Other examples are, among others; Lake Placid (1980), where the Organizing Committee for the Olympic Games almost went bankrupt; and Lillehammer (1994) and Athens (2004), which struggle with the problem of sporting facilities built for the occasion going into ruin. The Los Angeles Olympics in 1984 resulted in a profit, but in this case the early assumption was that private companies were to finance the event in exchange for advertisement [18]. Some studies show that sport tourism related to mega-events may have an adverse effect on other forms of tourism, in general contributing to the decrease of the number of tourists at a location. The phenomenon of crowding out scares off potential tourists because of crowds and the increase in prices during a major sporting event. If the event is hosted in season, regular visitors would simply not come. This has happened on the occasion of the Los Angeles Olympics in 1984 when there was a significant increase in the number of free hotel rooms during the event $[40,41]$. Hence, rather than the projected increase in the number of tourists, it can result in a drastic restructuring of the composition of visitors and even in a reduced number of tourists. Such a decrease has taken the organizers by surprise during the FIFA World Cup in Korea in 2002, when despite hosting a world-class sporting event, only approximately 400,000 spectators came, compared to the planned 650,000 (and this includes tourists for whom the championship was not the main reason for visiting) [42]. The example of Atlanta is also noteworthy (Olympic Games: 1996). During the year of the Olympics, the number of conferences held in Atlanta as compared to previous years dropped, the number of visitors decreased from 7.3 million to 6.7 million, and hotel occupancy decreased as well. An example of Athens where, during the 2004 Olympics, the Greek government bought the majority of tickets due to low demand and distributed them for free to all interested, shows that crowded events can actually dissuade tourists from visiting. UN WTO data prove that in the year of the Olympic Games in Athens, in comparison to the previous year, the number of foreign tourists in Greece had decreased from 14.0 million to 13.3 million. Before the Olympic Games in Barcelona, the citizens (16\%) also declared that they would leave the city for the duration of the event. The World Cup in Africa in 2010 is another example; some matches were played in nearly empty stadiums [43].

The matter of the so called "white elephants" remains a major issue. Many desolate sport facilities can be found in Africa and South America. Economists believe that very often investing in these expensive white elephant stadia does not pay for itself, because these facilities are unable to generate revenue. An example of such failed investment can be seen in stadia: Brasilia in Brazil (the second most expensive football stadium after Wembley); the World Football Championship 2010 stadium in Kaapstad (costing 600 million dollars, currently generates an 8 million dollar loss each year despite being used to organize high profile concerts); or Nelson Mandela Bay Stadium at Port Elizabeth in the Republic of South Africa. The white elephant effect is also noticeable in European stadia, for example, the facilities in Portugal after hosting the European Football Championship [44]. 
The various effects of organizing sporting mega-events have led to an increase in research into the Olympic legacy among recognized sports management specialists e.g., References [45-47]. The richest countries are already aware that the effects and legacy of the events may be negative, and sometimes they resign from bidding for the organization of the games in order to allocate funds for other social purposes. The middle-income countries, on the other hand, very much want to show the international community that they are equally good and organized hosts, which is why they more and more often endeavor to be known as the modern Olympia. Poland, which has already in the past made (unsuccessful) efforts to organize the Winter Olympic Games, may serve as an example. However, the European Football Championship was successfully organized in Poland in 2012. Countries such as Poland should draw on the experience of previous hosts in order to be able to assess whether it is better for them to organize the biggest sporting events (which most often also mean big problems) or rather to move towards smaller events, which are also popular, and thanks to which the city's development through the organization of an event can be more sustainable.

\subsection{Heritage Sporting Events and Tourism}

The sustainable development of sports tourism in recent years has also been supported by sports with long traditions and history. Contemporary cities and regions are increasing their prestige and image not only through the organization of major sporting events, such as the Olympic Games. This function is also performed by sporting events which are closely linked to the cultural heritage of sport in a given location. In particular, heritage sporting events or events which do not yet have a long tradition, but which may become a part of the cultural heritage of a given region in the future and are already fashionable among tourists and the local community. Generally speaking, the older the event, the deeper ingrained in part of the region's heritage it is and the stronger its brand in commercial terms. Mass sporting events, such as street marathons or bicycle races, in which any amateur can take part, are also gaining in importance in place marketing and the development of sports tourism.

Sport-related heritage is increasingly being recognized as a potent instigator of tourism. There has been growing acceptance within the sport tourism literature of the significance that the historical features of sport can play in generating tourism receipts. Such sport tourism attractions, whether in the form of halls of fame, sports stadia and museums, or traditional events, illustrate well the diversity of this emergent segment. These attractions usually have been placed within the nostalgia sport tourism realm and consequently been approached and interpreted from the related literature and less so from a heritage perspective. It has been argued that introducing the term heritage to this area of research adds depth to an already diverse topic [48].

As a result of the difficult and expensive race to organize major competitions, many cities and regions are turning also to smaller sporting events that do not require expensive infrastructure. They also want to avoid the problems related to the management of large sporting facilities, which may become deserted in the future and stop performing their functions. For several years there has been a discussion that small- and medium-scale sporting events can successfully contribute to the sustainable economic development of tourist destinations [49-51]. Researchers also point to positive social and cultural consequences for the local community [52]. Many small-size sporting events can be hosted by many cities, thereby generating benefits to host communities, which could surpass benefits of a one-off, large-scale event [53]. Evidence from several studies shows that small-scale sporting events may have more positive repercussions for the host community than major ones, in terms of both economic and social impacts [52,53].

Although many sporting events have close links with a particular city or place-for example, the tennis hall Roland-Garros in Paris-and are part of the heritage of the place, literature rarely combines the concepts of sporting event and heritage. "A cultural heritage sporting event can be defined as an event, generally involving a single sport, held at the same venue for many years and on a regular basis since its inception". Chappelet has introduced the term "Heritage Sporting Event (HSE)' for this type of sporting event linked to the cultural heritage of the region and of 
great importance to the community [36]. The impact of such events has rarely been analyzed in the scientific literature, with a much more frequent focus on major sporting events, such as the Olympic Games [54]. The HSEs with a high tourist significance, which play an important role in the modern marketing of places include, among others: Palio di Siena (famous horse races in Italian Siena); the Australian Open (Melbourne); Japanese Hatsu Basho (sumo, Tokyo); Internationaux de France Roland-Garros (Paris); the Sydney-Hobart Yacht Race (Sydney-Hobart); the Swiss Open (tennis, Switzerland); Giugno Pisano-a cultural and sports festival in Pisa, culminating in the historic regatta on the Arno River; the Mostar Bridge Diving Competition (in Mostar city); the ethno-cultural Braemar Highland Gathering Games in Scotland; the Venice Storica Regatta, held since the 12th century near the Canal Grande; Calcio Storico-a Florentine match combining wrestling, football, and rugby; the Wenlock Olympian Games (Much Wenlock, UK); the Monaco F1 Grand Prix; the traditional rowing regatta of Olavsoka Farers (kappródur) in the Faroe Islands; the Boston Marathon in the United States; the Tour de France; Turkish Kirkpinar-traditional men's wrestling in olive oil in Edirne (one of the oldest sports events in the world organized almost annually since 1640); and Wimbledon-a cult, legendary tournament for tennis fans (over 130 editions). Wimbledon is undoubtedly the most famous historical sporting event of all time. It is worth mentioning that such cities no longer have to apply and seek permission to organize such sporting events, so they do not have to compete with other regions, as in the case of the Olympic Games or the World Championships, for example. They are also experienced in organizing a given event, a larger or smaller one, and they are in possession of a database of trained volunteers.

Running tourism has been also very popular recently. We may witness how some of the running events are becoming a tradition of some tourist regions. Currently, the most popular running events in the world include: marathons in Athens, Lisbon, Gothenburg, Oslo, Warsaw, Budapest, and Prague; International Marathon of Peace-Kosice; Swiss City Marathon (Lucerne); The Midnight Sun Marathon (Tromso); Telenor Marathon (Copenhagen); as well as half-marathons in Geneva, Bucharest, Poznań, and Crete. As far as Poland is concerned, the Tour de Pologne (often awarded by the Polish Tourist Organisation) is a multi-stage road cycling race organized cyclically, being one of the most prestigious international sporting events in Poland has been organized regularly since 1928 and deserves the title of HSE beyond doubt. Initial ideas for conducting a multi-stage cycling event in independent Poland-modelled on the increasingly popular Tour de France-appeared as early as at the beginning of 1920s. The Polish Tourist Organisation has been supporting and using the Tour de Pologne race for several years in order to strengthen the image of the Polish tourist brand. In 2018, the 90th jubilee edition of this cult event, which is the strongest Polish sports brand in the world, took place.

\section{Material, Methods, and Aim of the Study}

\subsection{Aim of the Empirical Study}

The aim of the study was to examine whether there is a link between the rank of a sporting event and the development of tourism, the impact on the host city's image, and the social impact on hosts. Three sporting events taking place in Poznań-one of the largest Polish cities and the most important sports centers in Poland—were selected for empirical research.

\subsection{Research Design and Data Collection}

Sports events were selected randomly. The authors of the article received a calendar of sports events from the Municipal Office in Poznań City (Sports Department). All sporting events were grouped into three categories of different sporting rank-high, medium, and low, by the Municipal Office. From each group, one sporting event was drawn for research. The following three sporting events, which took place in the capital of the Greater Poland region, were used for the empirical studies: the 6th Poznań Half-Marathon-a mass running event attended mainly by amateur athletes; the Cavaliada international equestrian event attended by professional and amateur athletes; and the 
European Junior Swimming Championships, attended only by professional athletes. The first of the surveyed events-the 6th Poznań Half-Marathon-was an event in the field of mass sports, in which both amateur and professional athletes participated. The event is mainly national in nature, but in recent years it has become international. It is also an event that has become a permanent feature in the sports calendar of the city of Poznań. Running events have a long tradition in the capital of Greater Poland region, and the area is generally associated with this sports discipline. This event is of the lowest sporting rank among the surveyed events. However, it is slowly becoming an event strongly connected with the running traditions of Poznań. The second surveyed event was the third edition of Cavaliada. Cavaliada is an international equestrian event. The event consists of three parts: Cavaliada Sport, for top-level professionals; the Cavaliada Show, which also featured numerous amateur riders; and the Cavaliada Fair, an equestrian equipment fair. This event has an international reach and for several years has been successfully organized in the capital of Greater Poland and in several other Polish cities. The event is of an average sporting rank among the three surveyed events. The third surveyed event was the European Junior Swimming Championships, which took place in Poznan. Only professional athletes participated in the event. The opportunity to organize it in the capital of the Greater Poland region was a great success for Poznan. This event was of the highest sporting rank among all three examined events. The event does not take place cyclically in Poznań. These three events were selected for empirical studies because they are of different sporting ranks. The Half-Marathon's rank is the lowest, but it is an event strongly connected with the running traditions of the city. Running events have a long tradition in the capital of Greater Poland, and the region is generally associated with this sports discipline. Poland does not have many historic or traditional sports events. The most famous event of this type is Tour de Pologne. However, the authors of the article wanted to examine three different events, but taking place in the same city, so that the results of the study are not influenced by the attractiveness of the city itself. Moreover, Tour de Pologne is a cycling race and does not take place in just one city.

The study was attended by residents of the Poznan agglomeration and tourists. According to the UN WTO definition, a person who spent at least one night in Poznań using the available infrastructure was considered to be a tourist and whose motive for coming to Poznań was participation in a sports event as a fan or an athlete. It was assumed that a tourist is a person who lived more than $30 \mathrm{~km}$ from the city. Two types of interview questionnaires were prepared-for residents and tourists, in Polish and in English. Prior to the interview, the respondent was asked if they were a resident of the city and the surrounding areas, or if they met the criteria of being a tourist.

\subsection{Research Tool}

The method of a diagnostic survey was applied, which was the standardized interview technique with the use of the standardized interview questionnaire tool during the last day of events. In order to carry out the research, an original questionnaire was prepared to study the impact of sporting events on tourist destinations. The questions on the questionnaire concerned tourist behaviors among tourists, the impact of the event on the image of the city in the opinion of tourists and hosts, as well as the impact of the event on residents (impact of the event on the sense of local identity, pride, and social integration).

\subsection{Participants}

The survey was attended by active (athletes) and passive (sports fans) participants of events, both sports tourists and residents of Poznan. A total of 2098 people took part in the survey: 560 Half-Marathon athletes (210 inhabitants, 350 sport tourists), 510 Half-Marathon fans (256 inhabitants, 254 sport tourists), 818 Cavaliada fans (308 inhabitants, 510 sport tourists), and 210 athletes/sport-tourists of the European Junior Swimming Championships. For the tourists surveyed, the main motive for coming to Poznan was the willingness to take part in the event or to support it. Respondents were asked whether they had undertaken any additional tourism activity in the city thanks to participation in a sporting event and what kind of activity it was. They were 
also asked about their opinions on the impact of a given event on the image of the city of Poznan. The tables below present the socio-demographic profile (Table 1) of the respondents and the tourist behaviors they undertook (Table 2).

Table 1. Socio-demographic characteristics of surveyed participants (athletes and supporters).

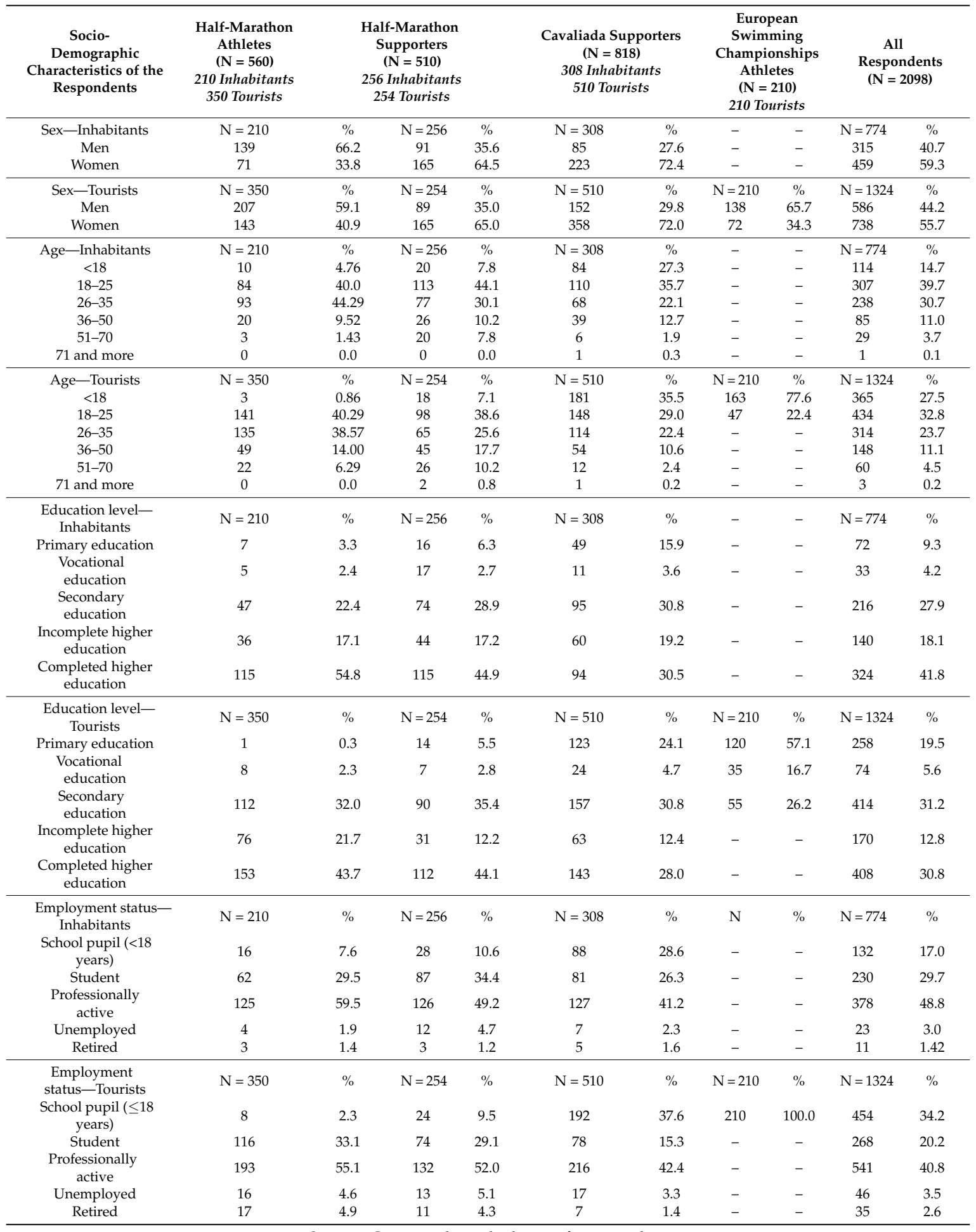


Table 2. The relation between surveyed participants of sporting events and tourism activities.

\begin{tabular}{|c|c|c|c|c|c|c|c|c|c|c|}
\hline & \multicolumn{2}{|c|}{$\begin{array}{l}\text { Half-Marathon } \\
\text { Athletes } \\
(\mathrm{N}=560)\end{array}$} & \multicolumn{2}{|c|}{$\begin{array}{l}\text { Half-Marathon } \\
\text { Supporters } \\
(\mathrm{N}=510)\end{array}$} & \multicolumn{2}{|c|}{$\begin{array}{l}\text { Cavaliada } \\
\text { Supporters } \\
(\mathrm{N}=818)\end{array}$} & \multicolumn{2}{|c|}{$\begin{array}{c}\text { European } \\
\text { Swimming } \\
\text { Championships } \\
\text { Athletes } \\
(\mathbf{N}=210)\end{array}$} & \multicolumn{2}{|c|}{ All } \\
\hline $\begin{array}{l}\text { participation in this } \\
\text { sporting event- }\end{array}$ & $N=210$ & $\%$ & $N=256$ & $\%$ & $\mathrm{~N}=308$ & $\%$ & - & - & $\mathrm{N}=543$ & $\%$ \\
\hline Inhabitants & & & & & & & & & & \\
\hline First Time & 116 & 55.2 & 151 & 59.0 & 96 & 31.2 & - & - & 363 & 66.8 \\
\hline Second Time & 41 & 19.5 & 51 & 19.9 & 60 & 19.5 & - & - & 152 & 28.0 \\
\hline Third Time & 26 & 12.4 & 20 & 7.8 & 152 & 49.4 & - & - & 198 & 36.4 \\
\hline Fourth Time & 16 & 7.6 & 14 & 5.5 & - & - & - & - & 30 & 5.5 \\
\hline Fifth Time & 8 & 3.8 & 20 & 7.8 & - & - & - & - & 28 & 5.1 \\
\hline Sixth Time & 3 & 1.4 & - & - & - & - & - & - & 3 & 0.5 \\
\hline $\begin{array}{c}\text { Frequency of } \\
\text { participation in this } \\
\text { sporting event- } \\
\quad \text { Tourists }\end{array}$ & $\mathrm{N}=350$ & $\%$ & $N=254$ & $\%$ & $\mathrm{~N}=510$ & $\%$ & - & - & $\mathrm{N}=1114$ & $\%$ \\
\hline First Time & 182 & 52.0 & 169 & 66.5 & 219 & 42.9 & - & - & 570 & 51.1 \\
\hline Second Time & 91 & 26.0 & 48 & 18.9 & 115 & 22.5 & - & - & 254 & 22.8 \\
\hline Third Time & 50 & 14.3 & 23 & 9.1 & 176 & 34.5 & - & - & 249 & 22.3 \\
\hline Fourth Time & 23 & 6.6 & 3 & 1.2 & - & - & - & - & 26 & 2.3 \\
\hline Fifth Time & 3 & 0.9 & 11 & 4.3 & - & - & - & - & 14 & 1.2 \\
\hline Sixth Time & 1 & 0.3 & - & - & - & - & - & - & 1 & 0.08 \\
\hline $\begin{array}{l}\text { Are you going to take } \\
\text { part in this event in } \\
\text { Poznań in the future? } \\
\text {-Inhabitants }\end{array}$ & $N=210$ & $\%$ & $N=256$ & $\%$ & $\mathrm{~N}=308$ & $\%$ & - & - & $\mathrm{N}=774$ & $\%$ \\
\hline Definitely Yes & 158 & 75.2 & 147 & 57.4 & 214 & 69.5 & - & - & 519 & 67.0 \\
\hline Probably Yes & 43 & 20.5 & 82 & 32.0 & 69 & 22.4 & - & - & 194 & 25.0 \\
\hline I do not know yet & 8 & 3.8 & 27 & 10.6 & 21 & 6.8 & - & - & 56 & 7.2 \\
\hline Probably Not & 1 & 0.5 & 0 & 0.0 & 4 & 1.3 & - & - & 5 & 0.06 \\
\hline Definitely Not & 0 & 0.0 & 0 & 0.0 & - & 0.0 & - & - & - & - \\
\hline $\begin{array}{c}\text { Are you going to take } \\
\text { part in this event in } \\
\text { Poznań in the future?- } \\
\text { Tourist }\end{array}$ & $\mathrm{N}=350$ & $\%$ & $N=254$ & $\%$ & $\mathrm{~N}=510$ & $\%$ & - & - & $\mathrm{N}=1114$ & $\%$ \\
\hline Definitely Yes & 207 & 59.1 & 118 & 46.5 & 348 & 68.2 & - & - & 673 & 60.4 \\
\hline Probably Yes & 108 & 30.9 & 88 & 34.7 & 128 & 25.1 & - & - & 324 & 29.1 \\
\hline I do not know yet & 310 & 8.9 & 39 & 15.3 & 28 & 5.5 & - & - & 98 & 8.8 \\
\hline Probably Not & 4 & 1.1 & 7 & 2.8 & 6 & 1.2 & - & - & 17 & 1.5 \\
\hline Definitely Not & 0 & 0.0 & 2 & 0.8 & 0 & 0.0 & - & - & 2 & 0.2 \\
\hline $\begin{array}{l}\text { Population of residence } \\
\text { (only tourists answered) }\end{array}$ & $\mathrm{N}=350$ & $\%$ & $N=254$ & $\%$ & $\mathrm{~N}=510$ & $\%$ & $N=210$ & $\%$ & $\mathrm{~N}=1324$ & $\%$ \\
\hline village & 97 & 27.7 & 75 & 29.5 & 145 & 28.6 & 23 & 11.0 & 340 & 25.7 \\
\hline $\begin{array}{l}\text { city up to } 10,000 \\
\text { inhabitants }\end{array}$ & 55 & 15.7 & 56 & 22.1 & 75 & 14.7 & 20 & 9.5 & 206 & 15.5 \\
\hline city $10-100,000$ & 121 & 34.6 & 72 & 28.4 & 150 & 29.4 & 34 & 16.2 & 377 & 28.5 \\
\hline city $100-500,000$ & 30 & 8.6 & 32 & 12.6 & 90 & 17.5 & 53 & 25.2 & 205 & 15.5 \\
\hline city over 500,000 & 47 & 13.4 & 19 & 7.5 & 50 & 9.8 & 80 & 38.1 & 196 & 14.8 \\
\hline $\begin{array}{l}\text { Length of stay in the } \\
\text { city of Poznań- } \\
\text { Tourists }\end{array}$ & $\mathrm{N}=350$ & $\%$ & $N=254$ & $\%$ & $\mathrm{~N}=510$ & $\%$ & $\mathrm{~N}=210$ & $\%$ & $\mathrm{~N}=1324$ & $\%$ \\
\hline 1 day & 84 & 24.0 & 85 & 33.5 & 216 & 42.4 & 0 & 0 & 386 & 29.1 \\
\hline 2 days & 146 & 41.7 & 81 & 31.9 & 108 & 21.2 & 0 & 0 & 335 & 25.3 \\
\hline 3 days & 62 & 17.7 & 34 & 13.4 & 93 & 18.2 & 10 & 4.8 & 199 & 15.0 \\
\hline 4 days & 58 & 16.6 & 54 & 21.3 & 93 & 18.2 & 75 & 35.7 & 280 & 21.1 \\
\hline 5 days and more & 0 & 0 & 0 & 0 & 0 & 0 & 125 & 59.5 & 125 & 9.4 \\
\hline $\begin{array}{l}\text { Additional tourist } \\
\text { activity in Poznań } \\
\text { during the participation } \\
\text { in the Half-Marathon }\end{array}$ & $\begin{array}{c}\text { YES } \\
82.9 \% \\
\mathrm{~N}=290\end{array}$ & $\%$ & $\begin{array}{c}\text { YES } \\
95.3 \% \\
\mathrm{~N}=182\end{array}$ & $\%$ & $\begin{array}{c}\text { YES } \\
60.8 \% \\
\mathrm{~N}=310\end{array}$ & $\%$ & $\begin{array}{c}\text { YES } \\
71.4 \% \\
\mathrm{~N}=150\end{array}$ & $\%$ & $\mathrm{~N}=932$ & $\%$ \\
\hline City tour—sightseeing & 201 & 69.3 & 132 & 72.5 & 176 & 56.8 & 106 & 70.7 & 615 & 66.0 \\
\hline Visit to a restaurant & 156 & 53.8 & 95 & 52.2 & 131 & 42.3 & 79 & 52.7 & 431 & 46.2 \\
\hline Shopping & 98 & 33.8 & 61 & 33.5 & 114 & 36.8 & 24 & 16.0 & 297 & 31.8 \\
\hline $\begin{array}{l}\text { Visit to a sports and } \\
\text { recreation facility } \\
\text { (e.g., swimming pool) }\end{array}$ & 28 & 9.7 & 22 & 12.1 & 21 & 6.8 & 23 & 15.3 & 94 & 10.0 \\
\hline $\begin{array}{l}\text { Participation in a cultural } \\
\text { event } \\
\text { (e.g., concert, theater) }\end{array}$ & 27 & 9.3 & 18 & 9.9 & 18 & 5.8 & 2 & 1.3 & 65 & 7.0 \\
\hline $\begin{array}{l}\text { Visit to the museum, } \\
\text { exhibition }\end{array}$ & 15 & 5.2 & 18 & 9.9 & 27 & 8.7 & 0 & 0.0 & 60 & 6.5 \\
\hline Other activity & 1 & 0.3 & 2 & 1.1 & 18 & 5.8 & 2 & 1.3 & 23 & 2.5 \\
\hline
\end{tabular}

Source: Own work on the basis of test results. 


\subsection{Data Analysis}

The analysis of relations between selected variables was carried out with the chi-squared test. The significance level was assumed to be $\alpha=0.05$. The results were considered statistically significant when the calculated test probability $p$ met the inequality $p<0.05$. A simple sampling scheme was applied without return. When determining the number of participants, information from the organizers on the expected number of participants in the event was used. In the calculations, the formula for the size of the sample of the finite population was used. The assumption was that the maximum estimation error (e) at $95 \%$ confidence level would not exceed $4 \%$. The authors of the article personally talked with the respondents. We tried to make the sample to be selected in a way that ensured the best possible representativeness of the results obtained. In the case of each athlete or supporter who met us, a coin was thrown (marked Yes/No). In the case that the coin showed Yes, the researcher approached the participant and asked to take part in the study. Unfortunately, due to the refusal by some participants (about 5-10\%), the sample was not chosen in a random manner, so it cannot be said that it was selected in a way that ensures the representativeness of results for the entire population. However, in such a dynamic situation of testing during the sporting events, there were simply no other options. Full randomization was not possible. The authors of the article received official permission from the organizers to conduct research. In the case of the Half-Marathon, permission for research among fans and athletes was obtained. In the case of the Cavaliada equestrian competition, permission was obtained only for research among fans. Due to the preparation of competitors for the start, they were not allowed to interfere with their training. Access to the players was therefore not possible. In the case of the Swimming Championships, permission was obtained for testing only among swimmers, but after the event, on the last day of the competition only.

\section{Results of Empirical Research}

\subsection{Ranking of a Sporting Event and Impact on Tourism Development}

Only sports tourists, $\mathrm{n}=1324$, who came to Poznań to take part in a sports event, were surveyed in this case: 350 active sports tourists taking part in the 6th Poznan Half-Marathon (tourists-athletes), 254 passive sports tourists taking part in the 6th Poznań Half-Marathon (tourists-supporters), 510 passive sports tourists taking part in Cavaliada (tourists-supporters), 210 active sports tourists taking part in the European Junior Swimming Championships (tourists-athletes). The conducted research showed a significant correlation between participation in an event of various sporting rank and undertaking additional tourist activity in Poznań, as shown in Table 3, where the higher the rank of the sporting event, the lower the additional tourist activity of participants in the city. Additional tourist activity was understood as visiting the city, going out to a restaurant, going shopping, participating in a cultural event, or visiting a sports and recreation center. The aforementioned regularity can be observed both among athletes (participants of the European Championships in swimming and the Half-Marathon), as well as fans (of the Half-Marathon and Cavaliada). The highest percentage of tourist activity in the city in the case of athletes and fans concerns the participants of the Half-Marathon. Despite the fact that the Half-Marathon is of the lowest sporting rank among the surveyed events, the participants of the running event most often used the tourist offerings of the city of Poznań.

Table 3. Additional tourist activity of participants in the analyzed sporting events (analysis for the group of athletes).

\begin{tabular}{ccccc}
\hline \multirow{2}{*}{ Tourist Activity } & \multicolumn{2}{c}{ European Swimming Championships } & \multicolumn{2}{c}{ Half-Marathon } \\
\cline { 2 - 5 } & $\mathbf{N}=\mathbf{2 1 0}$ & $\mathbf{\%}$ & $\mathbf{N}=\mathbf{5 6 0}$ & $\boldsymbol{\%}$ \\
\hline Yes & 150 & $71.4 \%$ & 290 & $82.9 \%$ \\
No & 60 & $28.6 \%$ & 60 & $17.1 \%$ \\
Total & 210 & $100 \%$ & 350 & $100 \%$ \\
\hline Chi-Square test result & \multicolumn{3}{c}{$\chi^{2}=10.2 ; \mathrm{df}=1 ; p=0.0014$} \\
\hline
\end{tabular}

Source: Own work on the basis of test results. 
Additional tourist activity (understood as city sightseeing, participation in a cultural event, visit toa museum, but also shopping, visit to a restaurant, visit to a sports and recreation facility, etc.) in the city where the event took place was $82.9 \%$ of Half-Marathon athletes ( 290 out of 350 people) and $71.4 \%$ of the European Swimming Championships athletes (150 out of 210 people). The analysis carried out using the chi-square test showed that there is a statistically significant relationship between the variables $(p=0.0014)$.

Differences in tourist activity can also be observed among fans. The additional tourist activity in the city was undertaken by $71.7 \%$ of Half-Marathon fans (182 out of 254 people) and $60.8 \%$ of Cavaliada fans (310 out of 510 people). The test result in this case is also statistically significant $(p=0.0031$ ) (Table 4$)$.

Table 4. Additional tourist activity of participants in the analyzed sporting events (analysis for the group of supporters).

\begin{tabular}{ccccc}
\hline \multirow{2}{*}{ Tourist Activity } & \multicolumn{2}{c}{ Half-Marathon } & \multicolumn{2}{c}{ Cavaliada } \\
\cline { 2 - 5 } & $\mathbf{N}=\mathbf{2 5 4}$ & $\mathbf{0}$ & $\mathbf{N}=\mathbf{5 1 0}$ & $\boldsymbol{\%}$ \\
\hline Yes & 182 & $71.7 \%$ & 310 & $60.8 \%$ \\
No & 72 & $28.4 \%$ & 200 & $39.2 \%$ \\
Total & 254 & $100 \%$ & 510 & $100 \%$ \\
\hline Chi-Square test result & \multicolumn{3}{c}{$\chi^{2}=8.7 ; \mathrm{df}=1 ; p=0.0031$} \\
\hline
\end{tabular}

Source: Own work on the basis of test results.

On the basis of the above analyses, it can be concluded that if a sporting event is characterized by a high sporting rank, and a high level of sporting competition takes place within its duration, its participants focus primarily on participating in competitions and no longer find time and perhaps the need to undertake additional tourism activity in the city (as the city's tourist infrastructure was used more often by athletes participating in the Half-Marathon). The situation was similar in the group of fans-if sports competitions are very attractive, they will not look for other forms of leisure time management. The diagnostic survey showed that the charms of Poznan and its tourist and recreation infrastructure were more frequently used by fans of the Half-Marathon than by those of Cavaliada—the event with the higher rank than the running event.

\subsection{The Rank of the Sporting Event and Impact on the Host City's Image}

All respondents who took part in the survey during three sporting events $(n=2098)$ were asked what the event's impact on the host city's image was, in their opinion. The analysis of responses carried out by means of the chi-square test indicates the existence of a statistically significant correlation between the sporting rank of the event and the impact on the improvement of the city's image (Table 5). It turns out that in the case of the events under study, the lower the sporting rank of the event, the greater the impact on the improvement of the host city's image. Therefore, it turns out that in order to improve the image of the city, it is also worth organizing sporting events of a lower rank, for example, mass street running; and not only elite events, because information about the former probably reaches a wider audience and thus enables a greater improvement in the image of the tourist destination. However, only a small group of sports amateurs may be interested in elite competitions. In the case of running, there is no need to build any specialized sports infrastructure, so there are no high costs of the event and its preparation takes place in a more sustainable way. Additionally, when we organize the same event every year in the same place, we already have experience in how to organize and manage it, and elite sports competitions always take place in a different place and always mean new challenges for the hosts. 
Table 5. Rank of the sporting event vs host city's image (all events in total).

\begin{tabular}{|c|c|c|c|c|c|c|c|c|}
\hline \multirow[t]{2}{*}{ Impact on Image } & \multicolumn{2}{|c|}{$\begin{array}{c}\text { European } \\
\text { Swimming } \\
\text { Championships }\end{array}$} & \multicolumn{2}{|c|}{ Half-Marathon } & \multicolumn{2}{|c|}{ Cavaliada } & \multicolumn{2}{|c|}{ Total } \\
\hline & $\mathbf{N}$ & $\%$ & $\mathbf{N}$ & $\%$ & $\mathbf{N}$ & $\%$ & $\mathbf{N}$ & $\%$ \\
\hline $\begin{array}{l}\text { Exerts positive impact on the city's } \\
\text { image }\end{array}$ & 135 & $64.29 \%$ & 1020 & $95.33 \%$ & 773 & $94.50 \%$ & 1928 & $91.89 \%$ \\
\hline \multirow{2}{*}{$\begin{array}{l}\text { Exerts no impact on the city's image } \\
\text { Exerts negative impact on the city's } \\
\text { image }\end{array}$} & 26 & $12.38 \%$ & 33 & $3.08 \%$ & 22 & $2.69 \%$ & 81 & $3.86 \%$ \\
\hline & 5 & $2.38 \%$ & 1 & $0.09 \%$ & 2 & $0.24 \%$ & 8 & $0.38 \%$ \\
\hline I don't know & 44 & $20.95 \%$ & 16 & $1.50 \%$ & 21 & $2.57 \%$ & 81 & $3.86 \%$ \\
\hline Total & 210 & & 1070 & & 818 & & 2098 & \\
\hline \multirow{2}{*}{\multicolumn{3}{|c|}{ Statistics }} & \multicolumn{6}{|c|}{ Statistics: Impact on image (4) $\times$ event $(3)$} \\
\hline & & & \multicolumn{2}{|c|}{ chi-square } & \multicolumn{2}{|c|}{ df } & \multicolumn{2}{|c|}{$p$} \\
\hline \multicolumn{3}{|l|}{$\mathrm{Chi}^{\wedge} 2$ Pearson } & \multicolumn{2}{|c|}{266.1513} & & \multicolumn{2}{|c|}{$p=0.0000$} \\
\hline \multicolumn{3}{|l|}{$\mathrm{Chi}^{\wedge} 2 \mathrm{NW}$} & \multicolumn{2}{|c|}{166.3768} & \multicolumn{2}{|c|}{$\mathrm{df}=6$} & \multirow{2}{*}{\multicolumn{2}{|c|}{$p=0.0000$}} \\
\hline \multicolumn{3}{|l|}{$\mathrm{Fi}$} & \multicolumn{2}{|c|}{0.3561735} & & & & \\
\hline \multicolumn{3}{|l|}{ Contingency factor } & \multicolumn{2}{|c|}{0.3355264} & & & & \\
\hline \multicolumn{2}{|l|}{ Cramér's V } & & \multicolumn{2}{|c|}{0.2518527} & & & & \\
\hline
\end{tabular}

Source: Own work on the basis of test results.

The host respondents $(n=774)$ were also asked about the immaterial/intangible effects of the events on the local community. The residents of Poznan were asked questions about the impact of an event in their city on the growth of pride, local community, and social integration, as well as local identity. This time, 210 athletes of the Half-Marathon from Poznań, 256 fans of the Half-Marathon from Poznan, and 308 fans of Cavaliada from Poznań, took part in the survey. The athletes of the Half-Marathon $(n=210)$ in the vast majority decided that the organization of a cyclical sporting event in their city for several years now, which is the Half-Marathon, increases the sense of local community and social integration. This was the response of $94.3 \%$ of the respondents $(5.7 \%$ thought that this was not the case). Those who responded affirmatively $(n=198)$ rated this impact at an average level of 8.1 points on the 10-point Likert scale (1-very low impact, 10-very high impact). A positive impact on the increase in pride due to the organization of the Half-Marathon in the place of residence was recorded by $97.1 \%(n=204)$ of the respondents at the average level of 8.2 points. The impact of the event on the increase in local identity was recorded by $94.8 \%$ of respondents $(n=199)$ at the average level of 8.1 points. In the case of Half-Marathon supporters $(n=256), 90.2 \%(n=231)$ of the respondents reported a positive impact on the sense of community at the level of 7.8 points. An increase in pride among residents was observed by $93.8 \%$ of the respondents $(n=240)$ at the level of 8.0 points, and an increase in local identity was observed by $93.4 \%(n=239)$ of the respondents at the level of 7.8 points. These were the responses of the participants of the Half-Marathon, i.e., the event of the lowest sporting rank.

For Cavaliada fans ( $\mathrm{n}=308)$-an event of a higher sporting rank-the results are as follows: the impact of the event on the sense of community and integration was observed by $64.6 \%(n=199)$ of people at an average level of 7.2 points, i.e., almost $25 \%$ lower and almost one point lower than Half-Marathon fans. In the case of pride, the result was $83.1 \%(n=256)$ at the level of 7.6 points, i.e., $10 \%$ less than Half-Marathon fans. Cavaliada's positive impact on local identity was declared by $74.7 \%$ of fans $(n=230)$ at a level of 7.2 points, i.e., almost $20 \%$ less than Half-Marathon supporters.

Research results also confirm that the lower the rank of a sports event, the higher the impact on the sense of pride, local community, and social identity among the hosts. The result of the chi-squared test between Half-Marathon supporters and Cavaliada supporters is as follows: local community $p=0.0000$; local identity $p=0.0000$; sense of pride $p=0.0001$. All the results are: $p<0.05$ (Table 6). 
Table 6. The impact of sporting events on the feeling of local community and social integration, pride, as well as local identity, among hosts.

\begin{tabular}{ccccccc}
\hline \multirow{2}{*}{ Kind of Impact (\%) } & \multicolumn{2}{c}{ Local Community/Social Integration } & \multicolumn{2}{c}{ Local Identity } & \multicolumn{2}{c}{ Sense of Pride } \\
\cline { 2 - 7 } & $\mathbf{N}$ & $\%$ & $\mathbf{N}$ & $\%$ & $\mathbf{N}$ & $\%$ \\
\hline Half-Marathon Athletes & 198 & 94.3 & 199 & 94.8 & 204 & 97.1 \\
$\quad \mathbf{N}=\mathbf{2 1 0}$ hosts \\
Half-Marathon Supporters & $\mathbf{N}=\mathbf{2 5 6}$ hosts \\
$\begin{array}{c}\text { Cavaliada Supporters } \\
\mathbf{N}=\mathbf{3 0 8} \text { hosts }\end{array}$ & 231 & 90.2 & 239 & 93.4 & 240 & 93.8 \\
\hline
\end{tabular}

Source: Own work on the basis of test results.

\section{Discussion and Conclusions}

Sport tourism, including sporting event tourism, fulfills a number of important socio-cultural functions in the modern world. The most important include enabling sports tourists to build a sense of connection and integration with other people, thanks to which the sports event becomes a post-modern form of participation in social life. Sporting events also satisfy the desire to experience strong emotions, a need that occupies a high place in the hierarchy of post-modern human needs. On the side of the hosts and organizers, sporting events perform a number of important functions as well. The most important ones include building a sense of community and local identity. Events also influence the sense of pride among residents due to the organization of important sporting events. Sporting events are also a stimulus for the development of tourism in the region and avenue for improving destination image.

Events related to the heritage of the sport of a given region and other smaller-scale sporting events, including mass sports and recreation events (e.g., marathon running) provide an alternative to homogenized, commercial, and very expensive sporting events in the world. For several decades now, researchers have focused on one-off events, especially the largest international competitions always taking place elsewhere and their impact on the social, political, and economic development of the regions. On the other hand, historical sporting events and mass sporting and recreational events addressed at all sporting enthusiast levels and their impact have not been studied in literature on a large scale, especially in countries as little experienced in this field as Poland, which so far has not been the host of many important sporting events. This is therefore a relatively new issue. The time has come, therefore, to pay more attention to events related to heritage sporting events and to lower rank sporting events, as they may contribute to the sustainable development of tourist regions and may have an equally strong or even stronger impact on the development of tourism and the improvement of the places' image than one-off elite sporting competitions.

The aim of the study was to examine whether there is a link between the rank of a sporting event and the development of tourism and the impact on the host city's image. Empirical studies have shown that such a relationship exists. The hypothesis that the lower the sports rank of the event, the higher the impact on the tourist revival in the city and the improvement of the image of the city turned out to be true. The results of the study showed that the highest additional tourism activity in the city on the occasion of participation in an event as an athlete or supporter was undertaken by the participants of the lowest rank sporting event (Half-Marathon). They also gave the highest rating of the positive impact of a sporting event on the host city's image. Research conducted during events also confirm that the lower the rank of a sports event, the higher the impact on the sense of pride, local community, and social identity among the hosts. (However, it should be added that although the Half-Marathon had the lowest sports rank among the analyzed events, it was already the 6th edition of this mass running event. Perhaps the result would not be so high if it was an event organized for the first time). The study of the social impact of small-scale sports events is important because so far researchers have focused mainly on measuring the social impact of large events [55].

Research results presented in the article provide information on the impact of small-scale sports events on tourism development and on improving the image of a tourist destination. They also provide 
valuable information on the social impact of small-scale sports events on hosts. Practical information is also valuable-if a given host wants to develop tourism in the city through the organization of sports events, mass sports events should also be organized, and not only elite competitions of the highest rank, because they do not always allow their participants to take full advantage of the city's tourist infrastructure. The analysis has shown that the higher the sporting rank of the event, the lower the additional tourism activity in the city among its participants. Moreover, more athletes take part in mass events than in elite competitions of the highest rank. More athletes in the city also means that they are more likely to take advantage of the tourist, recreational, and cultural infrastructure. Additionally, mass events of lower rank are not as expensive as elite competitions and in the case of running events, they do not require special infrastructure. From the point of view of tourism, it is therefore better to organize sporting events for all, not just top-level sporting events. The situation may, of course, be different in the case of mega-events, such as the Olympic Games or the largest football tournaments. Such events attract many more supporters than sporting events of a different rank. The impact of such an event on the development of various forms of tourism in a city may, therefore, be potentially much higher.

Apart from recognizing the tourist behaviors of participants of small-scale sports events (the majority of research concerns tourist expenses [7]), the scientific value of the article is also the socio-demographic characteristics of the participants of the events studied, as shown in Table 1. As Ritchie claims, profiling sports tourists attending small-scale sporting events can provide insights into market segments which have tourism potential [56]. There is also a need for complementary activities that can be of use to sports tourism event planners and government officials interested in maximizing the effectiveness of sporting initiatives [57].

We note the following strength and limitation of our study: a strength is the number of athletes and supporters investigated, while a limitation is the self-reporting, declarative nature of the surveys. In the future, the Likert scale should also be used to study the image of the place. This will allow to examine how the image changes depending on socio-demographic characteristics because some research results indicate that the image of sports events is significantly different from socio-demographic variables, i.e., gender or age [58].

The results of empirical studies and reflections contained in this article may inspire the organization of small-scale sporting events and the care for sporting events related to the (often forgotten) intangible cultural heritage of a given region. In the case of such events, the intangible social dimension may also be clearer, which is confirmed by the results of empirical studies presented in this article.

Finally, it is worth noting that small-scale sports events and events associated with the cultural heritage of a given region with long traditions provide opportunities for sustainable tourism development. First of all, they do not have to compete for the rights to organize. Secondly, the hosts can use the existing sports infrastructure and already have experience in organizing the event. Thirdly, street-style sporting events build tourists' loyalty to the events, which translates into destination loyalty. Tourists often take part in the same event many times in the same city every year. Such loyalty cannot be built by organizing mega sporting events, such as the Olympics, as they always take place in a different corner of the globe.

In other words, there is not one strategy that is appropriate for all cities, but certainly there is a best strategy for each city. The host cities must be aware of what the organization of a sporting event means, not so much in terms of technical feasibility, but rather in terms of political and human capital, by taking a multidisciplinary approach, and fostering visionary leadership, capable of governing, but also capable of sharing values, concerted actions, mobilizing resources, and looking towards the future of community [59].

Author Contributions: Conceptualization-E.M.-M., Methodology-E.M.-M., Software-J.P., Validation-E.M.-M., Formal Analysis-E.M.-M., Investigation-E.M.-M., Resources-E.M.-M., Data curation-E.M.-M. \& J.P., 
Writing-Original Draft Preparation-E.M.-M., Writing—Review \& Editing-E.M.-M., Visualization-E.M.-M. \& J.P., Supervision-E.M.-M., Project Administration-E.M.-M.

Funding: This research received no external funding.

Conflicts of Interest: The authors declare no conflict of interest.

\section{References}

1. World Travel E Tourism Council-Annual Report; World Travel \& Tourism Council: London, UK, 2018.

2. Wilson, R. The economic impact of local sport events: Significant, limited or otherwise? A case study of four swimming events. Manag. Leis. 2006, 11, 57-70. [CrossRef]

3. Dos Santos, M.A. Strategies in Sports Marketing: Technologies and Emerging Trends; Business Science Reference: Hershey, PA, USA, 2014.

4. Higham, J. Commentary-Sport as an Avenue of Tourism Development: An Analysis of the Positive and Negative Impacts of Sport Tourism. Curr. Issues Tour. 1999, 2, 82-90. [CrossRef]

5. Maennig, W.; Zimbalist, A. International Handbook on the Economics of Mega Sporting Events; Edward Elgar Publishing: Cheltenham, UK, 2012.

6. Matheson, V.A. Mega-Events: The Effect of the World's Biggest Sporting Events on Local, Regional, and National Economies; Holy Cross Working Paper Series; Holy Cross: Worcester, MA, USA, 2006.

7. Kwiatkowski, G.; Oklevik, O. Primary Economic Impact of Small-scale Sports Events. Event Manag. 2017, 21, $269-280$. [CrossRef]

8. Gibson, H. Active Sport Tourism: Who Participate? Leis. Stud. 1998, 17, 155-170. [CrossRef]

9. Hinch, T.; Higham, J. Sport and Tourism — Globalization, Mobility and Identity; Elsevier: Burlington, NJ, USA, 2009.

10. Hinch, T.; Higham, J. Sport Tourism Development; Channel View Publications: Bristol, UK, 2011.

11. Ramshaw, G.; Gammon, S. More than just Nostalgia? Exploring the heritage/sport tourism nexus. J. Sport Tour. 2006, 10, 229-241. [CrossRef]

12. Cantelon, H.; Letters, M. The making of the IOC environmental policy as the third dimension of the Olympic Movement. Int. Rev. Sociol. Sport 2000, 35, 294-308. [CrossRef]

13. Ritchie, J.R.B. Assessing the impacts of hallmark events: Conceptual and research issues. J. Travel Res. 1984, 23, 2-11. [CrossRef]

14. Jago, L.K.; Shaw, R.N. Special events: A conceptual and definitional framework. Festiv. Manag. Event Tour. 1998, 5, 21-32. [CrossRef]

15. Hall, C. Adventure, Sport and Health Tourism. In Special Interest Tourism; Weiler, B., Hall, C., Eds.; Bellhaven: Londyn, UK, 1992.

16. Moyle, B.; Higham, J.; Hinch, T. Sport Tourism and Sustainable Destinations; Routledge: London, UK, 2018.

17. Hinch, T.; Higham, J. Sport tourism and sustainable destinations: Foundations and pathways. J. Sport Tour. 2016, 20, 3-4. [CrossRef]

18. Kozak, M. Wielkie imprezy sportowe-korzyść czy strata? Studia Regionalne i Lokalne 2010, 1, 48-68.

19. Standeven, J.; De Knop, P. Sport Tourism; Human Kinetics: Champaign, IL, USA, 1999.

20. Littlejohn, M.; Taks, M. Sport events and happiness: Towards the development of a measuring instrument. World Leis. J. 2016, 58, 255-266. [CrossRef]

21. Roberts, C. Sport and Adventure Tourism. In Research Themes for Tourism; Robinson, P., Heitmann, S., Eds.; CABI: Oxfordshire, UK, 2011.

22. Taks, M. Factors Affecting Repeat Visitation and Flow-on Tourism as Sources of Event Strategy Sustainability. J. Sport Tour. 2009, 14, 2-3. [CrossRef]

23. Taks, M. Governance in Sport and the Olympic Movement: The future of mega-sport events, 2017, Ancient Olympia-Greece, International Olympic Academy. In Proceedings of the 12th International Session for Educators of Higher Institutes of Physical Education, Athens, Greece, 17 June-1 July 2017.

24. Whitson, D.; Macintosh, D. The global circus: International sport, tourism, and the marketing of cities. J. Sport Soc. Issues 1996, 3, 278-295. [CrossRef]

25. Weed, M. Progress in sports tourism research? A meta-review and exploration of futures. Tour. Manag. 2009, 30, 615-628. [CrossRef]

26. Tomlinson, A.; Young, C. National Identity and Global Sports Events. In Suny Series on Sport, Culture and Social Relations; State University of New York Press: Albany, NY, USA, 2006. 
27. Chalip, L. Tourism and the Olympic Games. In The Legacy of the Olympic Games 1984-2000-International Symposium Lausanne 2002, Proceedings of the 5th Symposium of the International Chair in Olympism, Lausanne, Switzerland, November 2002; International Olympic Committee: Lausanne, Switzerland, 2003.

28. Carvalhedo, A. Tourism as Cultural Legacy of the Modern Olympic Games. In The Legacy of the Olympic Games 1984-2000 - International Symposium Lausanne 2002, Proceedings of the 5th Symposium of the International Chair in Olympism: Lausanne, Switzerland, December 2002; International Olympic Committee: Lausanne, Switzerland, 2003.

29. Weed, M. Sport Tourism Experience. J. Sport Tour. 2008, 13, 1-4. [CrossRef]

30. Chalip, L.; Green, B. Effects of Sport Event Media on Destination Image and Intention to Visit. J. Sport Manag. 2003, 17, 214-234. [CrossRef]

31. Kaplanidou, K.; Vogt, C. The Interrelationship between Sport Event and Destination Image and Sport Tourists' Behaviours. J. Sport Tour. 2007, 12, 183-206. [CrossRef]

32. Robinson, J. Global and World Cities: A View from off the Map. Int. J. Urban Reg. Res. 2002, 26, 531-554. [CrossRef]

33. Avraham, E. Media strategies for improving an unfavourable city image. Cities 2004, 21, 471-479. [CrossRef]

34. Baker, D.A.; Crompton, J.L. Quality, satisfaction and behavioural intentions. Ann. Tour. Res. 2000, $27,785-804$. [CrossRef]

35. Oom do Valle, P.; Albino Silva, J.; Mendes, J.; Guerreiro, M. Tourist Satisfaction and Destination Loyalty Intention: A Structural and Categorical Analysis. Int. J. Bus. Sci. Appl. Manag. 2006, 1, $25-44$.

36. Chappelet, J.L. Heritage Sporting Events and Place Marketing. 2015. Available online: www.core.ac.uk/ download/pdf/77151599.pdf (accessed on 1 October 2018).

37. Solberg, H.; Preuss, H. Major sport events and long-term tourism impacts. J. Sport Manag. 2007, 21, 785-804. [CrossRef]

38. Preuss, H. Aspects of Olympic Games Tourism. 2007. Available online: www.sete.gr (accessed on 1 October 2018).

39. Girginov, V.; Hills, L. A Sustainable Sports Legacy-Creating a Link between the London Olympics and Sports Participation. In Olympic Legacies-Intended and Unintended (Political, Cultural, Economic, Educational); Mangan, J.A., Dyreson, M., Eds.; Routledge: New York, NY, USA, 2012.

40. Santo, C. Economic impact of sport stadiums, teams, and events. In Sport and Public Policy-Social, Political, and Economic Perspectives; Santo, C., Mildner, G., Eds.; Human Kinetics: Champaign, IL, USA, 2010.

41. Preuss, H. A method for calculating crowding-out effect in sport mega-event impact studies: The 2012 FIFA World Cup. Dev. S. Afr. 2011, 28, 367-385. [CrossRef]

42. Lee, C.; Taylor, T. Critical reflections on the economic impact assessment of a mega-event: The case of 2002 FIFA World Cup. Tour. Manag. 2005, 26, 595-603. [CrossRef]

43. Owen, G. Estimating the cost and benefit of hosting Olympic Games: What can Beijing expect from its 2008 Games? Ind. Geogr. 2005, 3, 1-18.

44. Alm, J.; Solberg, H. Hosting major sports events: The challenge of taming white elephants. Leis. Stud. 2016, 35, 564-582. [CrossRef]

45. Chappelet, J.L. Mega sporting event legacies: A multifaceted concept. Papeles de Europa 2012, 25, 76. [CrossRef]

46. Girginov, V. Rethinking Olympic Legacy; Routledge: New York, NY, USA, 2018.

47. Preuss, H. The conceptualisation and measurement of mega sport event legacies. J. Sport Tour. 2007, 12, 3-4. [CrossRef]

48. Gammon, S.; Ramshaw, G. Heritage, Sport and Tourism, Sporting Pasts-Tourists Future; Routledge: New York, NY, USA, 2007.

49. Gibson, H.; Kaplanidou, K.; Kang, S.J. Small-scale event sport tourism: A case study in sustainable tourism. Sport Manag. Rev. 2012, 15, 160-170. [CrossRef]

50. Taks, M. Social sustainability of non-mega sport events in a global world. Eur. J. Sport Soc. 2013, 10, $121-141$. [CrossRef]

51. Taks, M.; Green, C.; Misener, L.; Chalip, L. Evaluating sport development outcomes: The case of a medium-sized international sport event. Eur. Sport Manag. Q. 2014, 14, 213-237. [CrossRef]

52. Duglio, S.; Beltramo, R. Estimating the Economic Impacts of a Small-Scale Sport Tourism Event: The Case of the Italio-Swiss Mountain Trail CollonTrek. Sustainability 2017, 9, 343. [CrossRef]

53. Agha, N.; Taks, M. A Theoretical Comparison of the Economic Imapct of Large and Small Events. Int. J. Sport Financ. 2015, 10, 199-216. 
54. Pinson, J. Heritage sporting events-Theoretical developments and configurations. J. Sport Tour. 2017, 21, $133-152$. [CrossRef]

55. Kim, W.; Jun, H.M.; Walker, M.; Drane, D. Evaluating the perceived social impacts of hosting large-scale sport tourism events: Scale development and validation. Tour. Manag. 2015, 48, 21-32. [CrossRef]

56. Ritchie, B.W. Exploring Small-Scale Sport Event Tourism. The Case of Rugby Union. In Sport Tourism. Interrelationships, Impacts and Issues; Ritchie, B.W., Adair, D., Eds.; Channel View Publications: Bristol, UK, 2004.

57. Daniels, M.; Norman, W. Estimating the Economic Impacts of Seven Regular Sport Tourism Events. J. Sport Tour. 2003, 8, 214-222. [CrossRef]

58. Lee, C.K.; Taylor, T.; Lee, Y.K.; Lee, B. The Impact of a Sport Mega-Event on Destination Image. Int. J. Hosp. Tour. Adm. 2008, 6, 27-45. [CrossRef]

59. Garau, C.; Balletto, G.; Mundula, L. A critical reflection on smart governance in Italy: Definition and challenges for a sustainable urban regeneration. In Smart and Sustainable Planning For Cities and Regions; Springer: Cham, Switzerland, 2015; p. 248.

(C) 2018 by the authors. Licensee MDPI, Basel, Switzerland. This article is an open access article distributed under the terms and conditions of the Creative Commons Attribution (CC BY) license (http:// creativecommons.org/licenses/by/4.0/). 